\title{
A New Two-Photon Ratiometric Fluorescent Probe for Detecting Alkaline Phosphatase in Living Cells
}

\author{
Xiaohong Zhou ${ }^{1,2}$, Yuren Jiang ${ }^{1, *}$, Xiongjie Zhao ${ }^{1}$ and Yao Zhu ${ }^{1}$ \\ 1 College of Chemistry and Chemical Engineering, Central South University, Changsha 410083, China; \\ zhouxh001@csu.edu.cn (X.Z.); 152301025@csu.edu.cn (X.Z.); 152311095@csu.edu.cn (Y.Z.) \\ 2 Environment Monitoring Department, Changsha Environmental Protection College, \\ Changsha 410004, China \\ * Correspondence: jiangyr@mail.csu.edu.cn; Tel.: +86-731-8888-7895; Fax: +86-731-8885-9988
}

Academic Editor: Derek J. McPhee

Received: 19 October 2016; Accepted: 22 November 2016; Published: 25 November 2016

\begin{abstract}
Alkaline phosphatase (ALP) is an important diagnostic indicator of many human diseases. To quantitatively track ALP in biosystems, herein, for the first time, we report an efficient two-photon ratiometric fluorescent probe, termed probe 1 and based on classic naphthalene derivatives with a donor- $\pi$-acceptor $(\mathrm{D}-\pi-\mathrm{A})$ structure and deprotection of the phosphoric acid moiety by ALP. The presence of ALP causes the cleave of the phosphate group from naphthalene derivatives and the phosphate group changes the ability of the intramolecular charge transfer (ICT) and remarkably alters the probe's photophysical properties, thus an obvious ratiometric signal with an isoemissive point is observed. The fluorescence intensity ratio displayed a linear relationship against the concentration of ALP in the concentration range from 20 to $180 \mathrm{U} / \mathrm{L}$ with the limit of detection of $2.3 \mathrm{U} / \mathrm{L}$. Additionally, the probe $\mathbf{1}$ is further used for fluorescence imaging of ALP in living cells under one-photon excitation $(405 \mathrm{~nm})$ or two-photon excitation $(720 \mathrm{~nm})$, which showed a high resolution imaging, thus demonstrating its practical application in biological systems.
\end{abstract}

Keywords: two-photon; ratiometric; alkaline phosphatase (ALP); intramolecular charge transfer (ICT)

\section{Introduction}

Alkaline phosphatase (ALP) is a hydrolase that catalyzes the dephosphorylation process of various substrates including nucleic acids, proteins, and carbohydrates [1,2]. As an important diagnostic enzyme, ALP has long been serving as a biomarker in enzyme immunoassays and molecular biology [3], as well as a diagnostic indicator of many human diseases [4]. The normal level of ALP activity in human serum is in a range of 40-150 U/L [5] and the abnormal level of serum ALP are commonly correlated to several diseases such as bone disease, liver dysfunction, breast and prostatic cancer, diabetes and so on [6,7]. Thus, it is highly desirable to develop a sensitive, selective approach to detect ALP in diagnostic and clinical assays.

Among various methods for alkaline phosphatase assay, fluorescence-based assay has drawn much attention because of its simplicity, high sensitivity and real-time detection [8-10]. Several fluorescence probes generated from conjugated polyelectrolyte [11-13], quantum dots [14-16], noble metal nanoclusters [17,18] and organic fluorophores [19-21] have been reported for the detection of ALP activities. Despite many achievements from the above-mentioned successful studies, all of them work under one-photon excitation, which requires a rather short excitation wavelength (usually $<500 \mathrm{~nm}$ ). Again, under these conditions, bioimaging applications are affected by such accompanying drawbacks as photobleaching, autofluorescence in cells and tissues, and shallow penetration depth $(<100 \mu \mathrm{m})$ [22-24]. An ideal tool to overcoming such limitations is two-photon microscopy (TPM), which involves fluorophore excitation by two low-energy (longer wavelength) photons [25-29]. 
There are many excellent properties, such as large two-photon active absorption cross-section, high fluorescence quantum yield and good photo-chemostability about naphthalene derivatives with a donor- $\pi$-acceptor (D- $\pi-A)$ structure, which has thus been employed extensively as an efficient two-photon platform for designing two-photon probes for various targets [30-33]. In this work, we have developed a naphthalene-based compound with ICT character as a fluorescent probe (probe 1, Scheme 1) for the detection of ALP. To the best of our knowledge, until now, there has been no two-photon fluorescent probe for the detection of ALP. As a recognizing group, the phosphate group can be released from the probe $\mathbf{1}$ in the presence of ALP, and the ICT ability of the phenolic hydroxyl is modulated through dephosphorylation. An ICT process from the cleavage of the phosphate group to the formation of phenolic hydroxyl leads to a bathochromic shift in emission bands, thus affording a two-photon ratiometric fluorescent probe toward ALP [34].
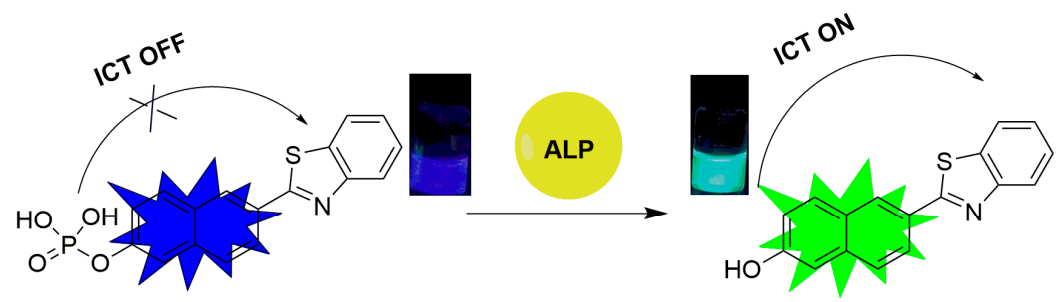

probe 1

compound 2 (two photon dye)

Scheme 1. Two-photon ratiometric probe 1's structure and detection mechanism toward ALP.

\section{Results and Discussion}

\subsection{Design and Response Principle of Probe $\mathbf{1}$}

Compound 2 shows excellent optical properties including a large two-photon active absorption cross-section, high fluorescence quantum yield and good photo-chemostability, rendering it a superior candidate for two-photon fluorescent probes [33]. Inspired by the importance of ALP activity assay and typical design strategy of ALP probes, we have modified compound 2 with a phosphate group, which serves as the recognition site of ALP. The phosphate group serving as a weak electron withdrawing group could reduce the electron donating ability of the oxygen atom of phenolic hydroxyl group, thus different ICT intensities occurred before and after the cleavage of phosphate group, resulting in obvious spectral shift and ratiometric signals (Figure S1 and Figure 1A). The sensing mechanism is illustrated in Scheme 1. The synthetic route to probe $\mathbf{1}$ is depicted in Scheme 2.

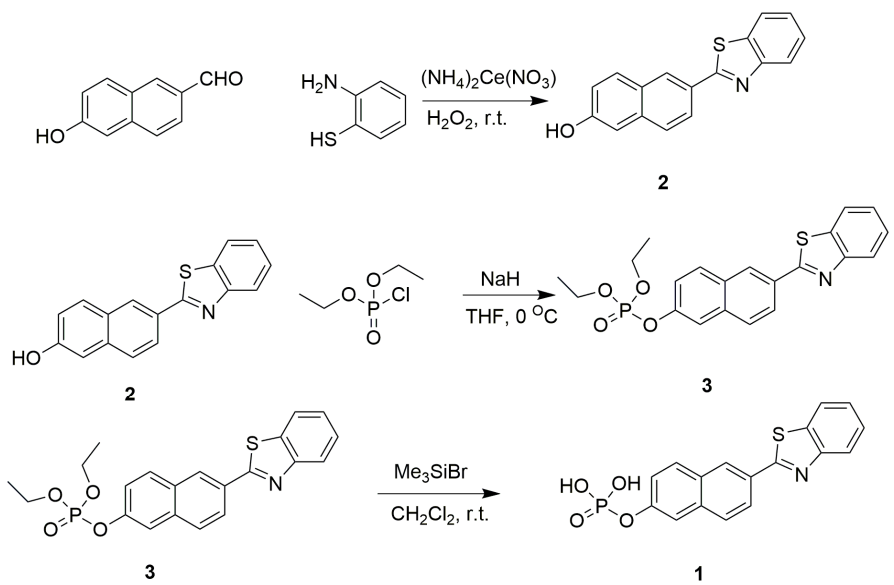

Scheme 2. Synthetic route to compound 3 and probe 1. 


\subsection{Analytical Spectral Properties of Probe $\mathbf{1}$}

Concentration-dependent monitoring of enzymatic reaction conducted to examine the possibility of quantitative analysis of ALP activity. As shown in Figure 1A, the fluorescence intensity at $428 \mathrm{~nm}$ decreased, while that at $508 \mathrm{~nm}$ increased along with ALP activity ranging from 0 to $180 \mathrm{U} / \mathrm{L}$. The fluorescence intensity ratio was plotted versus ALP concentration after probe 1 was incubated with different amount of ALP for $30 \mathrm{~min}$, and they exhibited a good linear relationship through a wide concentration range of 20-180 U/L with the limit of detection of $2.3 \mathrm{U} / \mathrm{L}$ (Figure 1B).

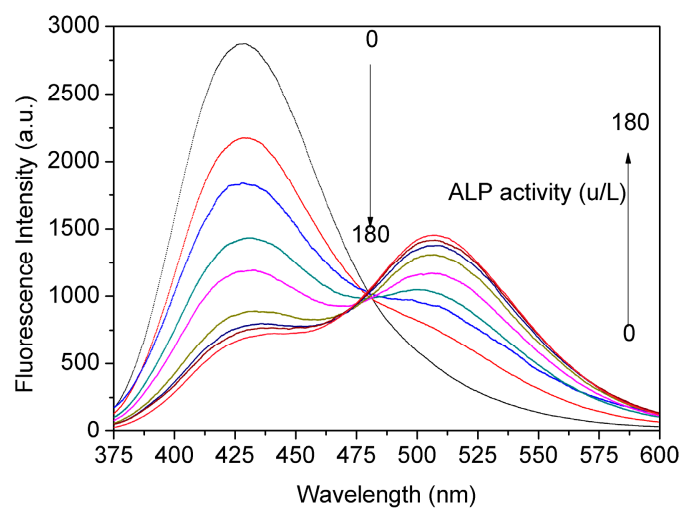

(A)

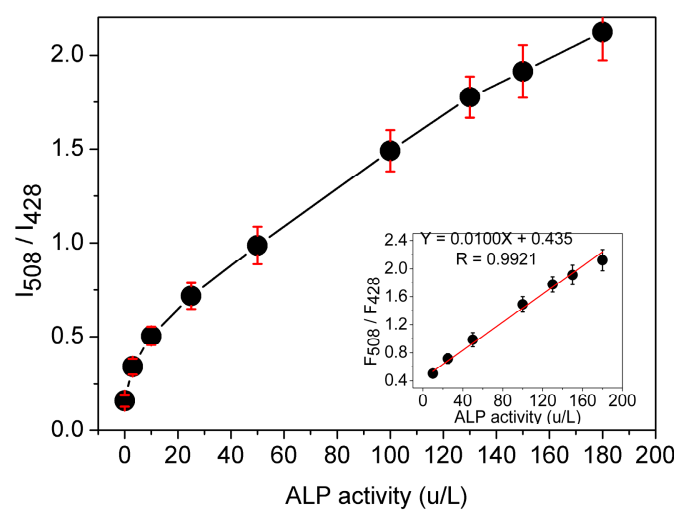

(B)

Figure 1. (A) Fluorescent spectra of probe $\mathbf{1}(10 \mu \mathrm{M})$ in Tris- $\mathrm{HCl}$ buffer solution $(\mathrm{pH} 7.4,10 \mathrm{mM})$ with $1 \%$ DMSO in the presence of different concentrations of ALP $(0-180 \mathrm{U} / \mathrm{L})$ at $37^{\circ} \mathrm{C}$; and (B) fluorescent intensity ratio $\left(\mathrm{I}_{508} / \mathrm{I}_{428}\right)$ as a function of ALP level, insert: the linearity of fluorescent intensity ratio $\left(\mathrm{I}_{508} / \mathrm{I}_{428}\right)$ as a function of ALP level, $\lambda_{\mathrm{Ex}}=360 \mathrm{~nm}$.

We then investigated the time-dependent fluorescent spectra of probe 1 in the presence of ALP at varied concentrations in Tris- $\mathrm{HCl}$ buffer solution $(\mathrm{pH} 7.4,10 \mathrm{mM}$ ) with $1 \%$ DMSO. As shown in Figure 2, the fluorescence intensity ratio $\left(\mathrm{I}_{508} / \mathrm{I}_{428}\right)$ of probe $\mathbf{1}(10 \mu \mathrm{M})$ after incubation with different amounts of ALP (0-180 U/L) had different time periods. Obviously, when the concentration of ALP was higher, the fluorescence intensity at $508 \mathrm{~nm}$ and the fluorescent intensity ratio $\left(\mathrm{I}_{508} / \mathrm{I}_{428}\right)$ were enhanced more rapidly. This is understandable by considering the fact that the hydrolysis of the probe would be facilitated in the presence of a high concentration of ALP. Moreover, the fluorescent intensity ratio $\left(\mathrm{I}_{508} / \mathrm{I}_{428}\right)$ reaches the maximum when the probe is incubated in the presence of ALP for $30 \mathrm{~min}$, indicating that the enzymatic reaction reaches a saturated state.

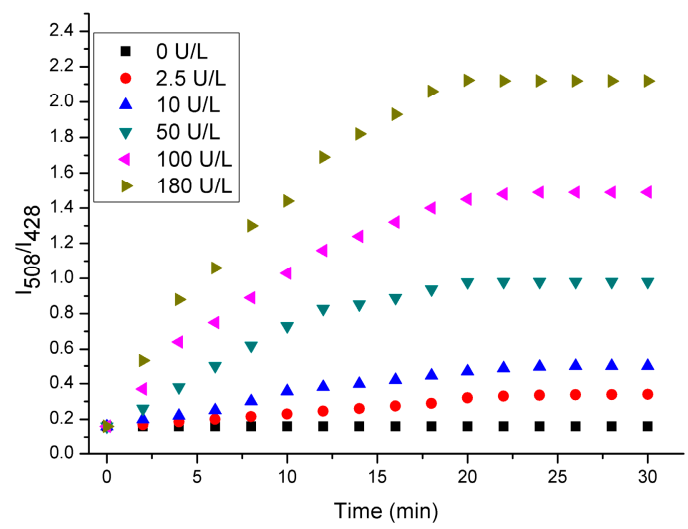

Figure 2. Time-dependent fluorescent spectra of probe $\mathbf{1}(10 \mu \mathrm{M})$ in in the presence of different amounts of ALP in Tris- $\mathrm{HCl}$ buffer solution ( $\mathrm{pH} 7.4,10 \mathrm{mM}$ ) with 1\% DMSO. 


\subsection{Effect of $p H$}

The effects of $\mathrm{pH}$ on the one-photon fluorescence intensity of $10 \mu \mathrm{M}$ probe $\mathbf{1}$ in the absence and presence of $100 \mathrm{U} / \mathrm{L}$ ALP were investigated in the $\mathrm{pH}$ range from 3 to 10 (Figure S2). As depicted in Figure S2, the emission spectra at $508 \mathrm{~nm}$ of probe 1 in the presence of ALP remained stable in the $\mathrm{pH}$ range from 6 to 10, and it was decreased in the acidic solution with $\mathrm{pH}$ from 5 to 3 . This result suggested that probe $\mathbf{1}$ was able to work over a relatively wide $\mathrm{pH}$ range. In this work, we used the physiological $\mathrm{pH}$ for the spectral tests.

\subsection{Selectivity Study}

To examine the selectivity of probe $\mathbf{1}$ towards phosphatase, we conducted a control experiment by treating probe $\mathbf{1}(10 \mu \mathrm{M})$ with other nonspecific proteins, such as lysozyme (100 U/L), bovine serum albumin (BSA, $0.5 \mathrm{mg} / \mathrm{mL}$ ), acetyl cholinesterase (AChE, $100 \mathrm{U} / \mathrm{L})$, trypsin $(100 \mathrm{U} / \mathrm{L}$ ) and esterase (100 U/L) under the same conditions. The results (Figure 3) showed that no significant fluorescence changes were observed; only the solution mixed with ALP (100 U/L) displayed an intense fluorescence signal at $508 \mathrm{~nm}$. There was about 8.7 -fold fluorescent intensity ratio $\left(\mathrm{I}_{508} / \mathrm{I}_{428}\right)$ enhancement over that of other proteins, which indicated the probe's high selectivity toward ALP.

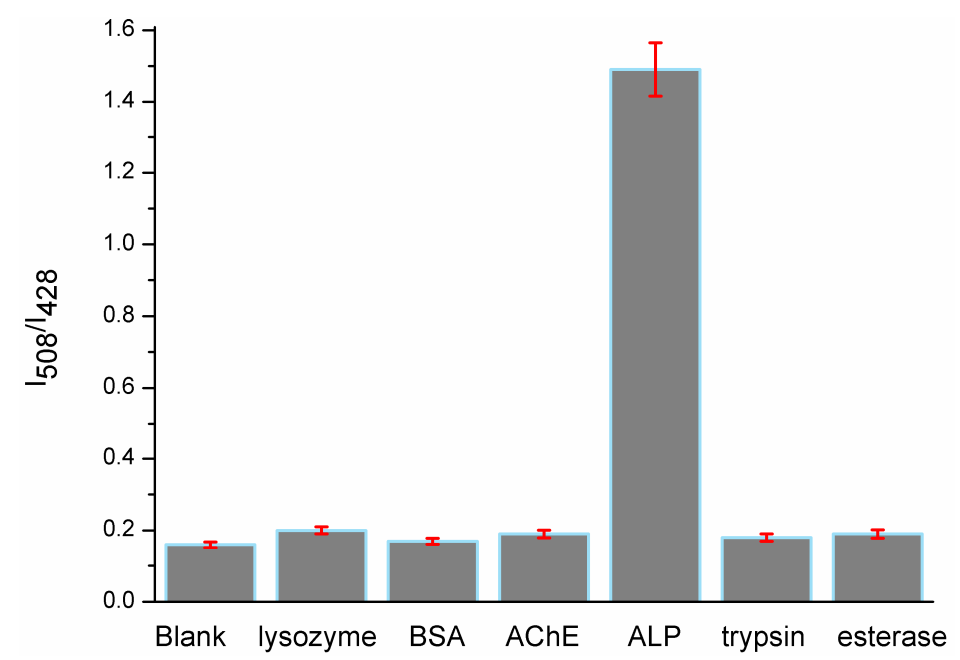

Figure 3. Fluorescent intensity ratio $\left(\mathrm{I}_{508} / \mathrm{I}_{428}\right)$ changes of probe $\mathbf{1}$ in the presence of lysozyme, BSA, AChE, ALP, trypsin and esterase in Tris- $\mathrm{HCl}$ buffer (pH 7.4, $10 \mathrm{mM}$ ) with 1\% DMSO.

\subsection{TP Fluorescence Propertiess}

The quantum yield for probe 1 was calculated to be 0.41 , and the quantum yield for compound 2 was 0.23 in ethanol with rhodamine B as the reference. In order to study the two-photon properties of the probe, the two-photon action absorption cross-section of probe $\mathbf{1}$ and compound $\mathbf{2}$ were calculated. Probe 1 was calculated to have 65 GM two-photon action absorption cross-section at $428 \mathrm{~nm}$ upon excitation at $720 \mathrm{~nm}\left(1 \mathrm{GM}=10^{-50}\left(\mathrm{~cm}^{4} \mathrm{~s}\right) /\right.$ photon) [35] (Figure 4, the blue line), and compound 2 was also calculated with $70 \mathrm{GM}$ at $508 \mathrm{~nm}$ upon excitation at $720 \mathrm{~nm}$. These results indicated that the probe $\mathbf{1}$ and compound $\mathbf{2}$ have good two-photon action absorption cross-section, and they are potentially useful for bioimaging applications. 


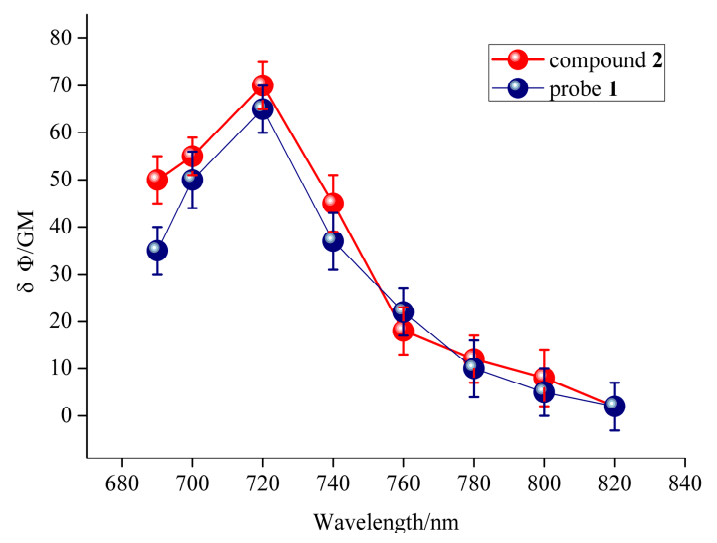

Figure 4. Two-photon action absorption cross-section of probe 1 and compound 2 in $\mathrm{CH}_{3} \mathrm{OH}$.

\subsection{Imaging of Endogenous ALP in Living Cells}

Inspired by the quantitative analysis of ALP in buffer solution, we further investigated whether the probe was able to monitor endogenous ALP activity in living cells. We first examined cytotoxicity of probe 1 by MTT assay. As shown in Figure S3, there was no significant reduction in cell viability after cells treated with the probe (from $5 \mu \mathrm{M}$ to $20 \mu \mathrm{M}$ ). The results showed that the probe has low toxicity in vitro.

Then, the probe's one-photon excited cell imaging was evaluated using Hela cells, in which ALP is overexpressed [36]. The imaging for endogenous ALP in the cells is shown in Figure 5A-E. HeLa cells incubated with the probe showed fluorescence enhancement both in blue and green channel, which is caused by the existence of endogenous ALP in HeLa cells and the production of compound 2. In the control test, HeLa cells were firstly incubated with ALP inhibitor levamisole hydrochloride for $30 \mathrm{~min}$ and then with the probe for another $30 \mathrm{~min}$. As shown in Figure 5F-J, the blue fluorescence was still obvious but the green fluorescence decreased significantly. These results indicated probe 1 could be triggered by endogenic ALP in living cells.

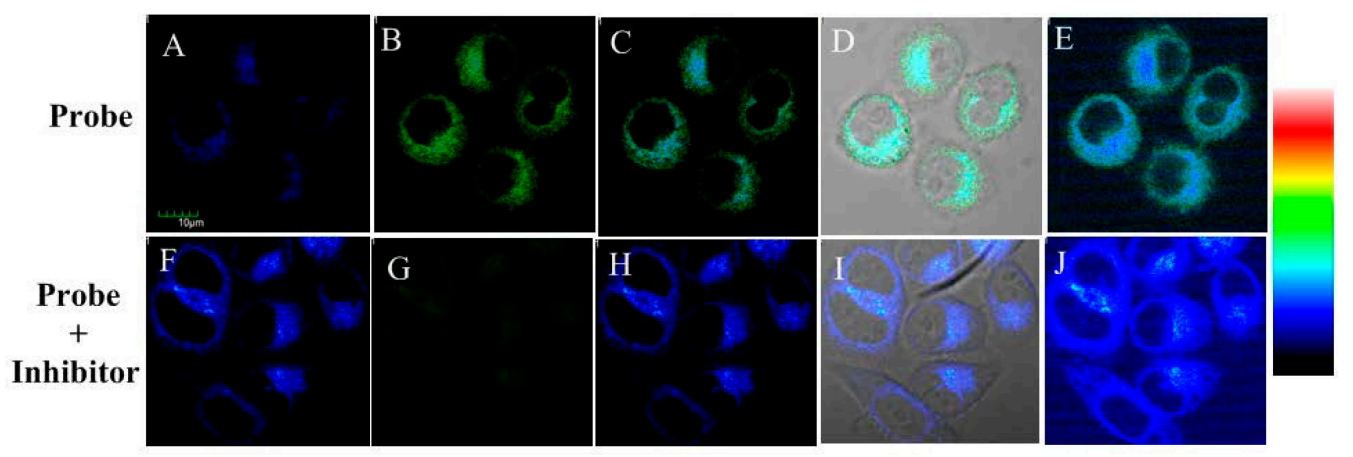

Figure 5. Fluorescence microscopy images for HeLa cells: (A-E) cells incubated with probe 1 for 30 min; and $(\mathbf{F}-\mathbf{J})$ cells incubated with inhibitor levamisole hydrochloride $(5 \mathrm{mM})$ for $30 \mathrm{~min}$ and then with the probe 1 for another $30 \mathrm{~min}$. (A,F) From blue channel; (B,G) from green channel; $(\mathbf{C}, \mathbf{H})$ overlay imaging of blue channel and green channel; (D,I) overlay imaging of blue channel, green channel and bright field; and (E,J) pseudo color imaging of blue channel and green channel. $\lambda_{\mathrm{Ex}}=405 \mathrm{~nm}$. Blue channel $\lambda_{\mathrm{Em}}: 410-460 \mathrm{~nm}$ and green channel $\lambda_{\mathrm{Em}}: 470-530 \mathrm{~nm}$. Scale bar: $10 \mu \mathrm{m}$.

Two-photon excited confocal fluorescence imaging experiment of probe 1 for endogenic ALP in living cells was then carried out, with results given in Figure 6. The two-photon microscopy imaging showed remarkable two-photon excited fluorescence enhancement after HeLa cells were incubated with $10.0 \mu \mathrm{M}$ probe 1 for $30 \mathrm{~min}$ at $37^{\circ} \mathrm{C}$ both in blue channel and green channel (Figure 6). 
This is because compound 2 has double emission peak, which confirms the hydrolysis and membrane permeability of probe $\mathbf{1}$. All of these results also demonstrated that probe $\mathbf{1}$ was suitable for direct two-photon imaging of ALP in biological samples.

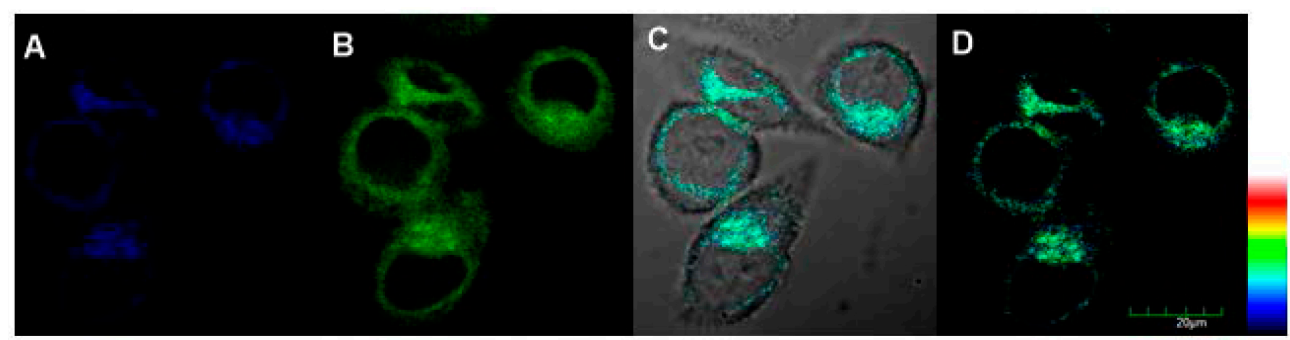

Figure 6. Two-photon fluorescent imaging of HeLa cells treated with probe $\mathbf{1}(10 \mu \mathrm{M})$ : (A) from blue channel; (B) from green channel; (C) overlay imaging of (A,B); and (D) pseudo color imaging of (A,B), $\lambda_{\text {TPEx }}=720 \mathrm{~nm}$, Blue channel $\lambda_{\mathrm{Em}}: 410-460 \mathrm{~nm}$ and green channel $\lambda_{\mathrm{Em}}: 470-530 \mathrm{~nm}$, Scale bar: $20 \mu \mathrm{m}$.

\section{Experimental Section}

\subsection{Materials and Apparatus}

All chemicals were obtained from commercial suppliers and used without further purification. Water was doubly distilled and purified by a Milli-Q system (Millipore, Billerica, MS, USA). NMR spectra were recorded on a Bruker DRX-500 spectrometer (Bruker, Karlsruhe, Germany) using TMS as an internal standard and dimethyl sulfoxide- $d_{6}\left(\right.$ DMSO- $\left.d_{6}\right)$ as solvent. Mass spectra were recorded using Agilent 6120 Quadrupole LC/MS from Agilent Technologies (Santa Clara, CA, USA). UV-vis absorption spectra were recorded on a Shimadzu-2450 UV-vis spectrophotometer (Kyoto, Japan). The $\mathrm{pH}$ was measured using a pH meter (pHS-3C, Shanghai Leici, Shanghai, China). Fluorescence measurements were carried out on a Hitachi-F4600 fluorescence spectrometer (Hitachi, Kyoto, Japan). Fluorescence images of HeLa cells were obtained using Olympus FV1000-MPE multiphoton laser scanning Confocal microscope (Tokyo, Japan).

\subsection{Synthesis}

Compound 2 was synthesized with 1,2-phenylenediamine and 6-hydroxy-2-naphthaldehyde under mild basic conditions with high yield [37]. Compound 2 was purified by silica gel chromatography with petroleum ether/ethyl acetate (1:1) as eluent to obtain white crystalline products. Compound 3 was then synthesized through phosphorylation of compound 2 with diethyl chlorophosphate in the presence of sodium hydride. Then, compound 3 was deprotected by bromotrimethylsilane to furnish probe $\mathbf{1}$ [38]. The structures of compound $\mathbf{3}$ and probe $\mathbf{1}$ were well characterized using ${ }^{1} \mathrm{H}-\mathrm{NMR},{ }^{13} \mathrm{C}-\mathrm{NMR},{ }^{31} \mathrm{P}-\mathrm{NMR}$ and MS (Figures S3-S9).

\subsection{Optical Property}

The fluorescence measurement experiments were measured in buffered $(10 \mathrm{mM}$ Tris- $\mathrm{HCl}, \mathrm{pH} 7.4$, $2 \mathrm{mM} \mathrm{MgCl} 2,0.2 \mathrm{mM} \mathrm{ZnCl}_{2}$ ) aqueous solvent with $1 \% \mathrm{DMSO}$ as co-solvent. The $\mathrm{pH}$ of buffer solution used was between 3.0 and 10.0. The fluorescent emission spectra were recorded at 375 to $600 \mathrm{~nm}$ (the excitation wavelength at $360 \mathrm{~nm}$ ) and absorption spectra were recorded at $300 \mathrm{to} 450 \mathrm{~nm}$. A $1 \times 10^{-3}$ M stock solution of probe 1 was prepared by dissolving probe 1 in DMSO. Procedure of calibration measurements with probe in the buffer was as follows: $10 \mu \mathrm{L}$ stock solution of probe and $990 \mu \mathrm{L}$ Tris- $\mathrm{HCl}$ buffer solution with different ALP concentration were combined to afford a test solution, which contained $1 \times 10^{-5} \mathrm{M}$ of probe 1 . 


\subsection{Cell Viability and Imaging}

The cytotoxic effects of the probe 1 were assessed using MTT assays [39]. The living Hela cells were seeded per well in a 96-well plate and incubated for $24 \mathrm{~h}$. Various concentrations $(0-20 \mu \mathrm{M})$ of the probe 1 were added into the 96-well plate and incubated for an additional $24 \mathrm{~h}$. Then, the cell was treated with MTT $\left(5 \mathrm{mg} \cdot \mathrm{mL}^{-1}\right)$. After incubation for $4 \mathrm{~h}$ under the same condition, all wells were measured the absorbance at $570 \mathrm{~nm}$, and cell viability of untreated cells was set to $100 \%$ as a reference. Each of the experiments was performed at least three times. For fluorescent imaging, cells were cultured in two confocal dishes in the culture medium overnight at $37^{\circ} \mathrm{C}$ under a $\mathrm{CO}_{2}$ $(5 \%)$ atmosphere. Then two confocal dishes were treated differently and imaged on an Olympus FV1000-MPE multiphoton laser scanning confocal microscope. In one dish, cells were incubated with probe $\mathbf{1}(10 \mu \mathrm{M})$ for $30 \mathrm{~min}$ before imaging. In another dish, cells were firstly incubated with ALP inhibitor levamisole hydrochloride (final concentration $5 \mathrm{mM}$ ) for $30 \mathrm{~min}$ and then with the probe $(10 \mu \mathrm{M})$ for another $30 \mathrm{~min}$ before imaging. One-photon excitation wavelength was fixed at $405 \mathrm{~nm}$, and the two-photon excitation wavelength of the femtosecond laser was fixed at $720 \mathrm{~nm}$. The emission wavelengths were recorded at $410-460$ and $470-530 \mathrm{~nm}$ respectively.

\subsection{The Fluorescent Quantum Yields and Two-Photon Excited Fluorescence Measurement}

The quantum yields of probe $\mathbf{1}$ and compound $\mathbf{2}$ was calculated by comparison with rhodamine $B$ in ethanol as a reference using the following equation:

$$
\Phi_{\mathrm{F}}=\mathrm{IA}_{\mathrm{R}}\left(\mathrm{n} / \mathrm{n}_{\mathrm{R}}\right)^{2} \Phi_{\mathrm{R}} / \mathrm{I}_{\mathrm{R}} \mathrm{A}
$$

where $\Phi_{\mathrm{F}}$ is the quantum yield, I is the integrated area under the fluorescence spectra, $\mathrm{A}$ is the absorbance, $\mathrm{n}$ is the refractive index of the solvent, and $\mathrm{R}$ refers to the reference rhodamine $\mathrm{B}$.

The two-photon excited fluorescence was measured by using a Ti as described [35]: sapphire femtosecond oscillator (Spectra Physics Mai Tai) as the excitation source. The output laser pulses have a tunable central wavelength from $690 \mathrm{~nm}$ to $1020 \mathrm{~nm}$ with pulse duration of less than $100 \mathrm{fs}$ and a repetition rate of $80.5 \mathrm{MHz}$. The laser beam was focused onto the samples using a lens with a focus length of $3.0 \mathrm{~cm}$. The emission was collected at an angle of $90^{\circ}$ to the direction of the excitation beam to minimize the scattering. The emission signal was directed into a CCD (Princeton Instruments, Pixis 400B, Acton, MA, USA) coupled monochromator (IsoPlane160) with an optical fiber. A $690 \mathrm{~nm}$ short pass filter was placed before the spectrometer to minimize the scattering from the excitation light. The two photon absorption (TPA) cross section ( $\delta$ ) of the sample (s) at each wavelength was calculated according to Equation (2), and rhodamine B in ethanol was used as the reference (r).

$$
\Delta=\delta_{\mathrm{r}} \times\left(\mathrm{S}_{\mathrm{s}} \times \Phi_{\mathrm{r}} \times \varphi_{\mathrm{r}} \times \mathrm{c}_{\mathrm{r}}\right) /\left(\mathrm{S}_{\mathrm{r}} \times \Phi_{\mathrm{s}} \times \varphi_{\mathrm{s}} \times \mathrm{c}_{\mathrm{S}}\right)
$$

where $S$ is the integrated fluorescence intensity, $\Phi$ is the fluorescence quantum yield, $C$ is the concentration of sample (s) and reference (r), and $\varphi$ is the collection efficiency of the experimental setup. The uncertainty in the measurement of cross sections is $\sim 15 \%$.

\section{Conclusions}

In summary, we have developed the first two-photon ratiometric fluorescent probe $\mathbf{1}$ for ALP based on the naphthalene derivative. The probe displays desirable properties such as high sensitivity, high selectivity and functioning well at physiological $\mathrm{pH}$. The proposed probe has been used for the determination of ALP in live cells for one- or two-photon fluorescence imaging, which showed high resolution imaging, thus demonstrating its practical application in biological systems. 
Supplementary Materials: Supplementary materials can be accessed at: http:/ /www.mdpi.com/1420-3049/21/ $12 / 1619 / \mathrm{s} 1$.

Acknowledgments: The National Natural Science Foundation of China (No. 20876180) is gratefully acknowledged for its financial support.

Author Contributions: Xiaohong Zhou designed the theme of the study and carried out the probe synthesis, as well as the manuscript preparation. Yuren Jiang responsible for the guidance of the manuscript. Xiongjie Zhao mainly contributed to manuscript revision. Yao Zhu contributed greatly to the image processing.

Conflicts of Interest: The authors declare no conflict of interest.

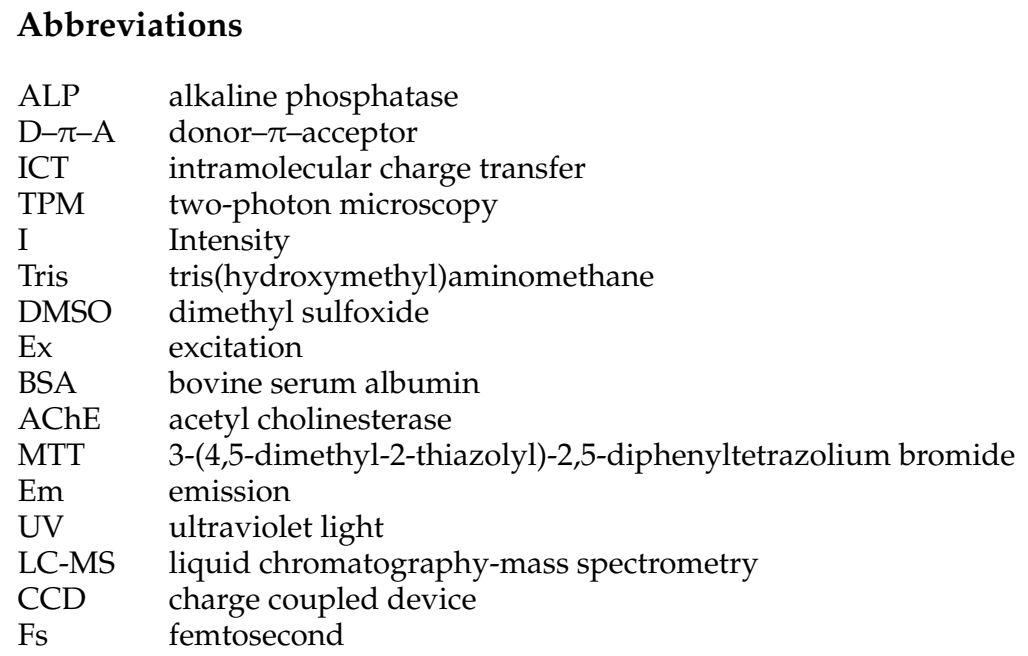

\section{References}

1. Syakalima, M.; Takiguchi, M.; Yasuda, J.; Hashimoto, A. A study of liver and corticosteroid-induced alkaline phosphatase isoenzymes activities associated with glucocorticoid hepatopathy in the dog. Jpn. J. Vet. Res. 1998, 46, 119-121.

2. Coleman, J.E. Structure and mechanism of alkaline phosphatase. Annu. Rev. Biophys. Biomol. Struct. 1992, 21, 441-483. [CrossRef]

3. Pike, A.F.; Kramer, N.I.; Blaauboer, B.J.; Seinen, W.; Brands, R. A novel hypothesis for an alkaline phosphatase 'rescue' mechanism in the hepatic acute phase immune response. Biochim. Biophys. Acta. 2013, 1832, 2044-2056. [CrossRef] [PubMed]

4. Song, Z.G.; Hong, Y.N.; Kwok, R.T.K.; Lam, J.W.Y.; Liu, B.; Tang, B.Z. A dual-mode fluorescence "turn-on" biosensor based on an aggregation-induced emission luminogen. J. Mater. Chem. B 2014, 2, 1717-1723. [CrossRef]

5. Ozer, J.; Ratner, M.; Shaw, M.; Bailey, W.; Schomaker, S. The current state of serum biomarkers of hepatotoxicity. Toxicology 2008, 245, 194-205. [CrossRef] [PubMed]

6. Chen, L.; Li, X.; Zheng, Z.; Lu, X.; Lin, M.; Pan, C.; Liu, J. A novel ATP7B gene mutation in a liver failure patient with normal ceruloplasmin and low serum alkaline phosphatase. Gene 2014, 538, 204-206. [CrossRef] [PubMed]

7. Kampanatkosol, R.; Thomson, T.; Habeeb, O.; Glynn, L.; DeChristopher, P.J.; Yong, S.; Jeske, W.; Maheshwari, A.; Muraskas, J. The relationship between reticulated platelets, intestinal alkaline phosphatase, and necrotizing enterocolitis. J. Pediatr. Surg. 2014, 49, 273-276. [CrossRef] [PubMed]

8. Lacivita, E.; Leopoldo, M.; Berardi, F.; Colabufo, N.A.; Perrone, R. Activatable fluorescent probes: A new concept in optical molecular imaging. Curr. Med. Chem. 2012, 19, 4731-4741. [CrossRef] [PubMed]

9. Hettiarachchi, S.U.; Prasai, B.; McCarley, R.L. Detection and cellular imaging of human cancer enzyme using a turn-on, wavelength-shiftable, self-immolative profluorophore. J. Am. Chem. Soc. 2014, 136, 7575-7578. [CrossRef] [PubMed]

10. Hu, R.; Liu, T.; Zhang, X.B.; Huan, S.Y.; Wu, C.C.; Fu, T.; Tan, W.H. Multicolor fluorescent biosensor for multiplexed detection of DNA. Anal. Chem. 2014, 86, 5009-5016. [CrossRef] [PubMed] 
11. Liu, Y.; Schanze, K.S. Conjugated polyelectrolyte-based real-time fluorescence assay for alkaline phosphatase with pyrophosphate as substrate. Anal. Chem. 2008, 80, 8605-8612. [CrossRef] [PubMed]

12. An, L.; Tang, Y.; Feng, F.; He, F.; Wang, S.J. Water-soluble conjugated polymers for continuous and sensitive fluorescence assays for phosphatase and peptidase. J. Mater. Chem. 2007, 17, 4147-4152. [CrossRef]

13. Zheng, F.Y.; Guo, S.H.; Zeng, F.; Li, J.; Wu, S.Z. Ratiometric fluorescent probe for alkaline phosphatase based on betaine-modified polyethylenimine via excimer/monomer conversion. Anal. Chem. 2014, 86, 9873-9879. [CrossRef] [PubMed]

14. Freeman, R.; Finder, T.; Gill, R.; Willner, I. Probing protein kinase $\left(\mathrm{CK}_{2}\right)$ and alkaline phosphatase with CdSe/ZnS quantum dots. Nano Lett. 2010, 10, 2192-2196. [CrossRef] [PubMed]

15. Jia, L.; Xu, J.P.; Li, D.; Pang, S.P.; Fang, Y.; Song, Z.G.; Ji, J. Fluorescence detection of alkaline phosphatase activity with $\beta$-cyclodextrin-modified quantum dots. Chem. Commun. 2010, 46, 7166-7168. [CrossRef] [PubMed]

16. Li, G.L.; Fu, H.L.; Chen, X.J.; Gong, P.W.; Chen, G.; Xia, L.; Wang, H.; You, J.M.; Wu, Y.N. Facile and sensitive fluorescence sensing of alkaline phosphatase activity with photoluminescent carbon dots Based on inner filter effect. Anal. Chem. 2016, 88, 2720-2726. [CrossRef] [PubMed]

17. Zhu, Y.H.; Wang, G.F.; Jiang, H.; Chen, L.; Zhang, X.J. One-step ultrasonic synthesis of graphene quantum dots with high quantum yield and their application in sensing alkaline phosphatase. Chem. Commun. 2015, 51, 948-951. [CrossRef] [PubMed]

18. Jiao, H.P.; Chen, J.; Li, W.Y.; Wang, F.Y.; Zhou, H.P.; Li, Y.X.; Yu, C. Nucleic acid-regulated perylene brobe-induced gold nanoparticle aggregation: A new strategy for colorimetric sensing of alkaline phosphatase activity and inhibitor screening. ACS Appl. Mater. Interfaces 2014, 6, 1979-1985. [CrossRef] [PubMed]

19. Dong, L.; Miao, Q.Q.; Hai, Z.J.; Yuan, Y.; Liang, G.L. Enzymatic hydrogelation-induced fluorescence turn-off for sensing alkaline phosphatase in vitro and in living cells. Anal. Chem. 2015, 87, 6475-6478. [CrossRef] [PubMed]

20. Zhang, H.M.; Xu, C.L.; Liu, J.; Li, X.H.; Guo, L.; Li, X.M. An enzyme-activatable probe with a self-immolative linker for rapid and sensitive alkaline phosphatase detection and cell imaging through a cascade reaction. Chem. Commun. 2015, 51, 7031-7034. [CrossRef] [PubMed]

21. Lu, Z.X.; Wu, J.S.; Liu, W.M.; Zhang, G.Y.; Wang, P.F. A ratiometric fluorescent probe for quantification of alkaline phosphatase in living cells. RSC Adv. 2016, 6, 32046-32051. [CrossRef]

22. Kuhn, B.; Denk, W.; Bruno, R.M. In vivo two-photon voltage-sensitive dye imaging reveals top-down control of cortical layers 1 and 2 during wakefulness. Proc. Natl. Acad. Sci. USA 2008, 105, 7588-7593. [CrossRef] [PubMed]

23. Dong, X.H.; Han, J.H.; Heo, C.H.; Kim, H.M.; Liu, Z.H.; Cho, B.R. Dual-color imaging of magnesium/calcium ion activities with two-photon fluorescent probes. Anal. Chem. 2012, 84, 8110-8113. [CrossRef] [PubMed]

24. Masanta, G.; Lim, C.S.; Kim, H.J.; Han, J.H.; Kim, H.M.; Cho, B.R. A mitochondrial-targeted two-photon probe for zinc ion. J. Am. Chem. Soc. 2011, 133, 5698-5700. [CrossRef] [PubMed]

25. Zhou, L.Y.; Lu, D.Q.; Wang, Q.Q.; Hu, S.Q.; Wang, H.F.; Sun, H.Y.; Zhang, X.B. A high-resolution mitochonghdria-targeting ratiometric fluorescent probe for detection of the endogenous hypochlorous acid. Spectrochim. Acta A Mol. Biomol. Spectrosc. 2016, 166, 129-134. [CrossRef] [PubMed]

26. Zhou, L.Y.; Hu, S.Q.; Wang, H.F.; Sun, H.Y.; Zhang, X.B. A novel ratiometric two-photon fluorescent probe for imaging of $\mathrm{Pd}^{2+}$ ions in living cells and tissues. Spectrochim. Acta. A Mol. Biomol. Spectrosc. 2016, 166, 25-30. [CrossRef] [PubMed]

27. Kim, H.M.; Cho, B.R. Two-photon probes for intracellular free metal ions, acidic vesicles, and lipid rafts in live tissues. Acc. Chem. Res. 2009, 42, 863-872. [CrossRef] [PubMed]

28. Zhu, A.W.; Ding, C.Q.; Tian, Y. A two-photon ratiometric fluorescence probe for cupric ions in live cells and tissues. Sci. Rep. 2013, 3, 2933. [CrossRef] [PubMed]

29. Kim, D.; Ryu, H.G.; Ahn, K.H. Recent development of two-photon fluorescent probes for bioimaging. Org. Biomol. Chem. 2014, 12, 4550-4566. [CrossRef] [PubMed]

30. Sarkar, A.R.; Kang, D.E.; Kim, H.M.; Cho, B.R. Recent development of two-photon fluorescent probes for bioimaging. Inorg. Chem. 2014, 53, 1794-1803. [CrossRef] [PubMed]

31. Lim, C.S.; Masanta, G.; Kim, H.J.; Han, J.H.; Kim, H.M.; Cho, B.R. Ratiometric detection of mitochondrial thiols with a two-photon fluorescent probe. J. Am. Chem. Soc. 2011, 133, 11132-11135. [CrossRef] [PubMed] 
32. Bae, S.K.; Heo, C.H.; Choi, D.J.; Sen, D.; Joe, E.H.; Cho, B.R.; Kim, H.M. A ratiometric two-photon fluorescent probe reveals reduction in mitochondrial $\mathrm{H}_{2} \mathrm{~S}$ production in Parkinson's disease gene knockout astrocytes. J. Am. Chem. Soc. 2013, 135, 9915-9923. [CrossRef] [PubMed]

33. Ma, Q.J.; Xu, J.H.; Zhang, X.B.; Zhou, L.Y.; Liu, H.W.; Zhang, J. A naphthalene-based two-photon fluorescent probe for selective and sensitive detection of thiophenols. Sens. Actuators B Chem. 2016, 229, 434-440. [CrossRef]

34. Xia, X.T.; Zeng, F.; Zhang, P.S.; Lyu, J.; Huang, Y.; Wu, S.Z. An ICT-based ratiometric fluorescent probe for hydrazine detection and its application in living cells and in vivo. Sens. Actuators B Chem. 2016, 227, 411-418. [CrossRef]

35. Zhou, L.; Lu, D.Q.; Wang, Q.; Hu, S.; Wang, H.; Sun, H.; Zhang, X. An efficient two-photon ratiometric fluorescent probe platform for dual-channel imaging of lysosomes in living cells and tissues. Sens. Actuators $B$ Chem. 2017, 238, 274-280. [CrossRef]

36. Hou, X.F.; Yu, Q.X.; Zeng, F.; Ye, J.H.; Wu, S.Z. A ratiometric fluorescent probe for in vivo tracking of alkaline phosphatase level variation resulting from drug-induced organ damage. J. Mater. Chem. B 2015, 3, 1042-1048. [CrossRef]

37. Bahrami, K.; Khodaei, M.M.; Naali, F. Mild and highly efficient method for the synthesis of 2-arylbenzimidazoles and 2-arylbenzothiazoles. J. Org. Chem. 2008, 73, 6835-6837. [CrossRef] [PubMed]

38. Hu, Q.H.; Zeng, F.; Yu, C.M.; Wu, S.Z. A fluorescent probe for alkaline phosphatase via excited state intramolecular proton transfer. Sens. Actuators B Chem. 2015, 220, 720-726. [CrossRef]

39. Zhou, X.H.; Jiang, Y.R.; Zhao, X.J.; Guo, D. A naphthalene-based two-photon fluorescent probe for selective and sensitive detection of endogenous hypochlorous acid. Talanta 2016, 160, 470-474. [CrossRef] [PubMed]

Sample Availability: Samples of the compounds 1, 2 and 3 are available from the authors.

(C) 2016 by the authors; licensee MDPI, Basel, Switzerland. This article is an open access article distributed under the terms and conditions of the Creative Commons Attribution (CC-BY) license (http://creativecommons.org/licenses/by/4.0/). 